\title{
Effect of prostaglandin F-2 $\alpha$ and uterine extracts on progesterone secretion in vitro by superfused pig corpora lutea
}

\author{
J. Watson and Felicity M. Maule Walker \\ Department of Biochemistry, University of Strathclyde, The Todd Centre, \\ 31 Taylor Street, Glasgow G4 ONR, U.K.
}

\begin{abstract}
Summary. Corpora lutea obtained from sows in the mid-luteal phase of the oestrous cycle were superfused with various doses of PGF- $2 \alpha$, uterine flushings or superfusates from endometrial strips. High doses of PGF- $2 \alpha(1-5 \mu \mathrm{g} / \mathrm{ml})$ gave transient stimulation of progesterone secretion; lower doses $(0 \cdot 1-1 \cdot 0 \mu \mathrm{g} / \mathrm{ml})$ inhibited secretion of the steroid, but to a maximum of $55 \%$ only and the secretion returned to control levels when superfusion with PGF-2 $\alpha$ stopped. Uterine flushings from sows in the late luteal phase of the cycle were more effective than mid-cycle flushings in inhibiting progesterone secretion by the luteal tissue: maximal inhibition was $65 \%$ and progesterone secretion slowly returned to control levels when superfusion with the flushings was stopped. Superfusate from strips of uterine endometrium from sows in the late luteal phase of the cycle proved most effective in inhibiting progesterone secretion ( $>90 \%$ ) and gave a long-lasting inhibition which did not appear to be due to stimulation of PGF-2 $\alpha$ secretion by the endometrium or corpus luteum.
\end{abstract}

\section{Introduction}

In the pig, the corpus luteum appears to be under uterine control because hysterectomy considerably prolongs its life-span (Spies, Zimmerman, Self \& Casida, 1960). Elevated levels of PGF-2 $\alpha$ in the utero-ovarian vein of sows during the late luteal phase of the oestrous cycle have been shown to be temporally related to declining plasma progesterone levels (Gleeson, Thorburn \& Cox, 1974). Although exogenously administered PGF-2 $\alpha$ is relatively ineffective in inducing luteolysis in the pig before Day 12 of the oestrous cycle (Diehl \& Day, 1973), a prostaglandin analogue (ICI 79,939) given between Days 12 and 15 of the cycle induces premature luteal regression and shortens the cycle (Guthrie \& Polge, 1976). Further, PGF-2 $\alpha$ will induce luteolysis in hysterectomized gilts (Moeljono, Bazer \& Thatcher, 1976) and pregnant sows (Diehl \& Day, 1974). Prostaglandin F-2 $\alpha$ has therefore been proposed as the uterine luteolysin in the sow.

A unilateral pregnancy in pigs fails within 21 days in the presence of a non-gravid uterine horn (Anderson, 1966), suggesting a systemic element as the luteolysin. The pig lung, however, is a good source of 15-hydroxyprostaglandin dehydrogenase, effectively metabolizing PGF- $2 \alpha$ in vitro (Hansen, 1976), and PGF-2 $\alpha$ seems unlikely to be systemically active.

The pig corpus luteum in vitro has a considerable capacity to secrete PGF-2 $\alpha$ during the late luteal phase of the cycle (Patek \& Watson, 1976) and this suggests that there may be a direct role for PGF- $2 \alpha$ within the ovary, perhaps stimulated by a uterine systemic factor. The present study was designed to test the effects of PGF-2 $\alpha$ and uterine extracts on progesterone secretion by superfused pig corpora lutea in vitro.

\section{Materials and Methods}

All chemicals were of AR grade and solvents were further purified by distillation in an all-glass system. [1,2,6,7-3 $\mathrm{H}]$ Pregn-4-ene-3,20-dione (progesterone: sp. act. $87 \mathrm{Ci} / \mathrm{mmol}$ ), $\left[2,4,6,7-{ }^{3} \mathrm{H}\right]$ oestra1,3,5(10)-triene-3,17 $\beta$-diol (oestradiol : sp.act. $85 \mathrm{Ci} / \mathrm{mmol}$ ), $\left[5,6,8,11,12,14,15(\mathrm{n})-{ }^{3} \mathrm{H}\right]$ prostaglandin 
F-2 $\alpha$ (sp.act. $130 \mathrm{Ci} / \mathrm{mmol}$ ) and $\left[5,6,11,14,15(\mathrm{n})-{ }^{3} \mathrm{H}\right]$ prostaglandin $\mathrm{B}-2$ (sp.act. $130 \mathrm{Ci} / \mathrm{mmol}$ ) were obtained from the Radiochemical Centre, Amersham, U.K. Medium 199 (type TC 45) and donkey anti-rabbit serum (DARS) were obtained from Wellcome Reagents Ltd, Beckenham, Kent, U.K. Scintillator for radioimmunoassays consisted of $2 \mathrm{~g}$ PPO and $0 \cdot 1 \mathrm{~g}$ POPOP (Koch-Light Laboratories Ltd, Colnbrook, Buckinghamshire, U.K.) dissolved in $800 \mathrm{ml}$ toluene and $200 \mathrm{ml}$ Triton X-100 (Hopkins \& Williams Ltd, Romford, Essex, U.K.). Radioactive samples were counted in a Nuclear Chicago Isocap 300 Liquid Scintillation Counter.

\section{Porcine endometrium and luteal tissue}

Intact ovaries plus uterus obtained from mature sows immediately after slaughter in the local abattoir were chilled and transported to the laboratory. The corpora lutea were carefully excised, trimmed free of connective tissue, assessed (see below) and sliced to a thickness of $0.4 \mathrm{~mm}$ with a hand microtome. Approximately $150 \mathrm{mg}$ tissue was used in each superfusion chamber. Endometrial strips were obtained from a region in the middle of the uterine horn by gently lifting the endometrial tissue from the uterus with forceps and slicing it into thin strips (350 mg/chamber was used). Each uterine horn was flushed carefully with $50 \mathrm{ml}$ medium $199(\mathrm{pH} \mathrm{7.4)}$; no change in the $\mathrm{pH}$ of the medium was observed during this process. The flushings were examined to check that there were no embryos present.

The stage of the oestrous cycle was assessed by careful examination of the corpora lutea and these were divided into early (Days 3-6), mid- (Days 7-15) and late (Days 16+) corpora lutea on the basis of visible and histological examination as described previously (Watson \& Leask, 1975). This ageing was supported by the gross morphology of the uterus. The mid-corpora lutea were subdivided into mid-I and mid-II (approximately Days 7-10 and 11-15 respectively) tissue on the basis of their vascularity.

\section{Superfusion}

Small Perspex chromatography columns (volume $2.5 \mathrm{ml}$ ) were used as superfusion chambers, and medium 199 was pumped through these, via heating coils, at a flow rate of $20 \mathrm{ml} / \mathrm{h}$ by a WatsonMarlow MHRK/4/Delta flow inducer. The effluent from the columns (superfusate) was collected in test-tubes in a fraction collector (LKB Ultrorac) every $50 \mathrm{~min}$ and, by using the second row of the fraction collector, 10 samples could be collected at any one time. Medium 199 was gassed with $95 \%$ $\mathrm{O}_{2}: 5 \% \mathrm{CO}_{2}$ and sterilized immediately before use by passing through a millipore filter. The whole apparatus was maintained in a cold room $\left(4^{\circ} \mathrm{C}\right)$ to prevent contamination. The heating coils and columns were placed in a water bath at $37^{\circ} \mathrm{C}$. The apparatus was sterilized between each experiment by flushing with $2 \cdot 5 \%(\mathrm{v} / \mathrm{v})$ sodium hypochlorite followed by sterile water then medium 199 .

Ten chambers were used in each experiment, two blank (medium only), two control and two for each substance under investigation. It was also possible to pass the superfusate from one chamber containing endometrial strips (termed endometrial superfusate) through a second chamber containing luteal tissue and small samples of endometrial superfusate could be collected through a small valve at the top of the chamber containing the endometrial strips.

Retention of radioactive steroids and $\mathrm{PGs}$ by the Perspex chambers and polyethylene tubing was found to be negligible.

\section{Analysis of samples}

Progesterone and PGF-2 $\alpha$ in the samples were measured by radioimmunoassays. All samples were checked for parallelism with the standard curve in every assay and at least three aliquot volumes were assayed in duplicate for every sample. Quality controls were made up on the day of the experiment so that storage time for the quality control and the experimental samples was the same. All quality controls were made up at a concentration of $5 \mathrm{ng} / \mathrm{ml}$. 
Progesterone. Progesterone was measured by a combination of an extraction technique (Watson \& Leask, 1975) which depends on the selective extraction of progesterone with specific batches of petroleum ether (b.p. $40-50^{\circ} \mathrm{C}$ ) and a double-antibody radioimmunoassay method based on the double-antibody procedure of Niswender \& Midgley (1970) as described below. The antibody, which was highly specific for progesterone, was raised in rabbits against $11 \alpha$-hydroxyprogesterone-11hemisuccinate-bovine serum albumin.

Petroleum ether extracts of suitable volumes of superfusates were evaporated to dryness in assay tubes. To each tube was then added $100 \mu \mathrm{l}$ of a solution of $\left[{ }^{3} \mathrm{H}\right]$ progesterone in buffer $(25 \mu \mathrm{Ci} / \mathrm{ml}$ $0.1 \mathrm{M}$-phosphate buffer containing $0.9 \%(\mathrm{w} / \mathrm{v}) \mathrm{NaCl}, 0.1 \%(\mathrm{w} / \mathrm{v})$ gelatin and $0.01 \%(\mathrm{w} / \mathrm{v})$ thimerosal) and $100 \mu \mathrm{l}$ antibody solution (diluted $1: 1500$ in buffer). Tubes containing progesterone standards (extracted as above), medium blanks, and assay controls were similarly prepared. The contents of each tube were mixed and incubated for $2 \mathrm{~h}$ at room temperature. Phosphate buffer $(200 \mu \mathrm{l})$, normal rabbit serum ( $50 \mu 1,1: 75$ dilution) and DARS ( $50 \mu \mathrm{l}, 3: 10$ dilution) were added to give a total volume in each tube of $0.5 \mathrm{ml}$. The dilutions of NRS and DARS were checked for each batch of reagent. The tubes were incubated overnight at $4^{\circ} \mathrm{C}$, centrifuged at $1200 \mathrm{~g}$ for $25 \mathrm{~min}$ at $4^{\circ} \mathrm{C}$ and decanted into scintillation vials containing scintillator. After counting, the radioactivity measurements were processed automatically by computer which plotted a standard curve for progesterone and gave values for each sample (Seaton, Lusty \& Watson, 1976).

The interassay coefficient of variation, calculated from quality controls, was $6.7 \%$, the mean quality control value being $5 \cdot 3 \mathrm{ng} / \mathrm{ml}$. The intra-assay coefficient of variation was $4.9 \%$. Blank sample values were always $<5 \mathrm{pg}$ progesterone $/ \mathrm{ml}$ medium 199 and adjustments for these values were not made.

Prostaglandin $F-2 \alpha$. This was measured by the double-antibody radioimmunoassay procedure of Dighe, Emslie, Henderson, Rutherford \& Simon (1975) with an antibody raised in rabbits against PGF-2 $\alpha$-bovine serum albumin. Superfusate aliquots of various volumes $(20-200 \mu \mathrm{l})$ were acidified with equal volumes of citrate buffer $(\mathrm{pH} 4.0)$ and extracted twice with 2 volumes of ethyl acetate: recovery of tritiated PGF- $2 \alpha$ was $>95 \%$. Radioimmunoassay of the dried extracts was then essentially the same as described above for progesterone except that tris buffer (pH 8 ) containing $0 \cdot 1 \%(w / v)$ gelatin was used.

The interassay coefficient of variation was $7 \cdot 3 \%$, the mean quality control value being $5 \cdot 44 \mathrm{ng} / \mathrm{ml}$. The intra-assay coefficient of variation was $5 \cdot 1 \%$. Blank sample values were always $<5 \mathrm{pg}$ PGF- $2 \alpha / \mathrm{ml}$ medium 199 and were therefore disregarded.

\section{Results}

Progesterone secretion from pig corpora lutea (mid-II stage) during superfusion in vitro for $5 \mathrm{~h}$ with various doses of PGF-2 $\alpha$ is shown in Text-fig. 1. Under control conditions, the luteal tissue secreted steady levels of progesterone and while the highest doses $(1-5.0 \mu \mathrm{g} / \mathrm{ml})$ of PGF-2 $\alpha$ gave a transient stimulation of progesterone secretion, decreasing the dose resulted in a progessive decline in progesterone secretion. The maximum reduction in progesterone secretion was about $55 \%$ relative to control conditions and lowering the dose of PGF- $2 \alpha$ below $0 \cdot 1 \mu \mathrm{g} / \mathrm{ml}$ caused no further decline. The secretion of progesterone always recovered almost to control levels immediately the superfusion with PGF-2 $\alpha$ was terminated.

When mid-II stage luteal tissue was superfused with uterine flushings obtained from sows in the late or mid-luteal phases of the oestrous cycle (Text-fig. 2), the mid-luteal phase flushings inhibited progesterone secretion by only $25 \%$ relative to control conditions, while the late luteal flushings proved more effective than any of the doses of PGF- $2 \alpha$ used above and reduced progesterone secretion from the tissue by some $65 \%$ relative to control conditions. The secretion of progesterone again returned to control levels, although this occurred gradually over several hours after the end of superfusion.

When the superfusate from chambers containing endometrial strips (endometrial superfusate) was passed over luteal tissue (mid-II stage) in other chambers, superfusate from endometrial strips 


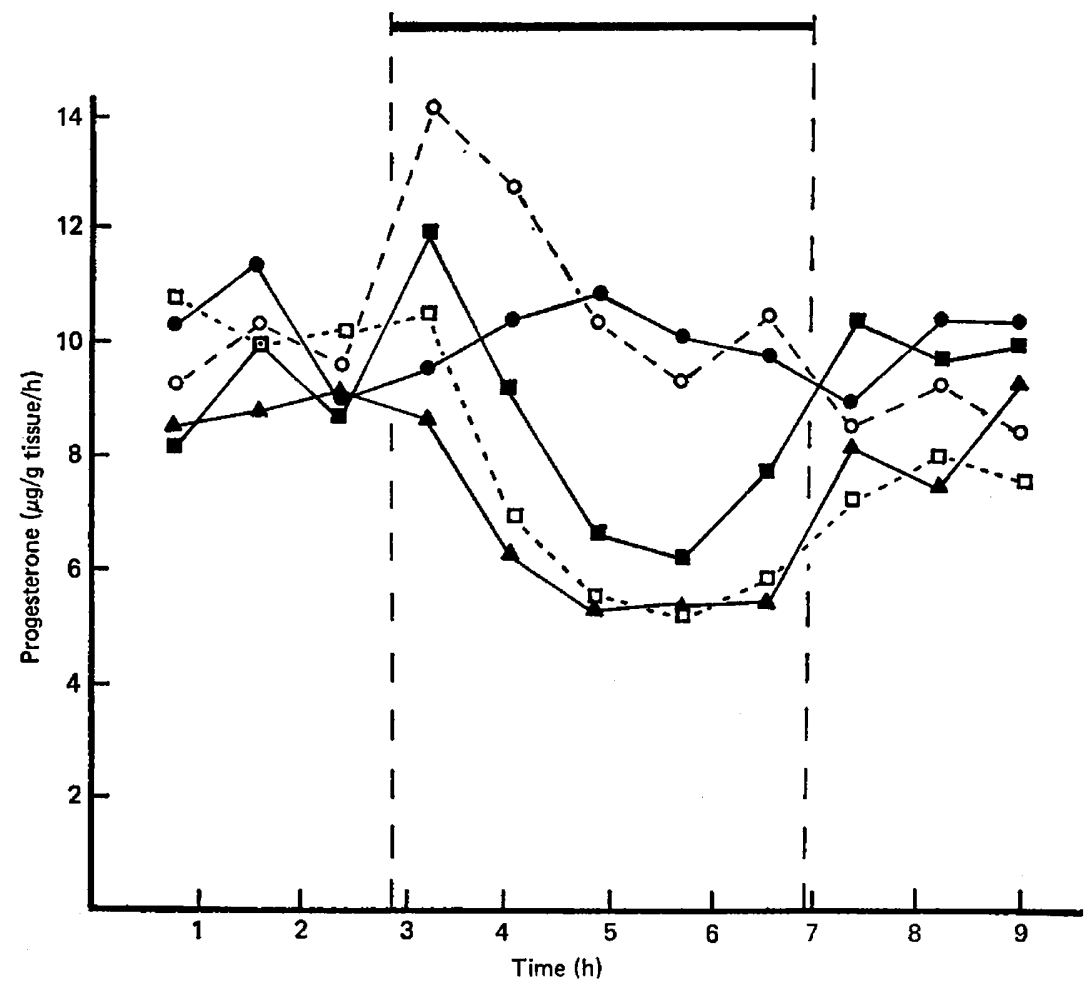

Text-fig. 1. Progesterone secretion by pig corpus luteum tissue (mid-II stage) superfused with medium 199 alone $(\bullet)$ or PGF- $2 \alpha(O, 5 \mu \mathrm{g} / \mathrm{ml} ; \square, 1 \mu \mathrm{g} / \mathrm{ml} ; \square, 0.5 \mu \mathrm{g} / \mathrm{ml} ; \Lambda, 0.1 \mu \mathrm{g} / \mathrm{ml})$ as indicated by the bar and vertical broken lines. Each point represents the mean of 5 experiments in which triplicate samples of superfusate were analysed in duplicate. S.E.M. values did not exceed $\pm 0.6 \mu \mathrm{g} \mathrm{g}^{-1} \mathrm{~h}^{-1}$ at any point.
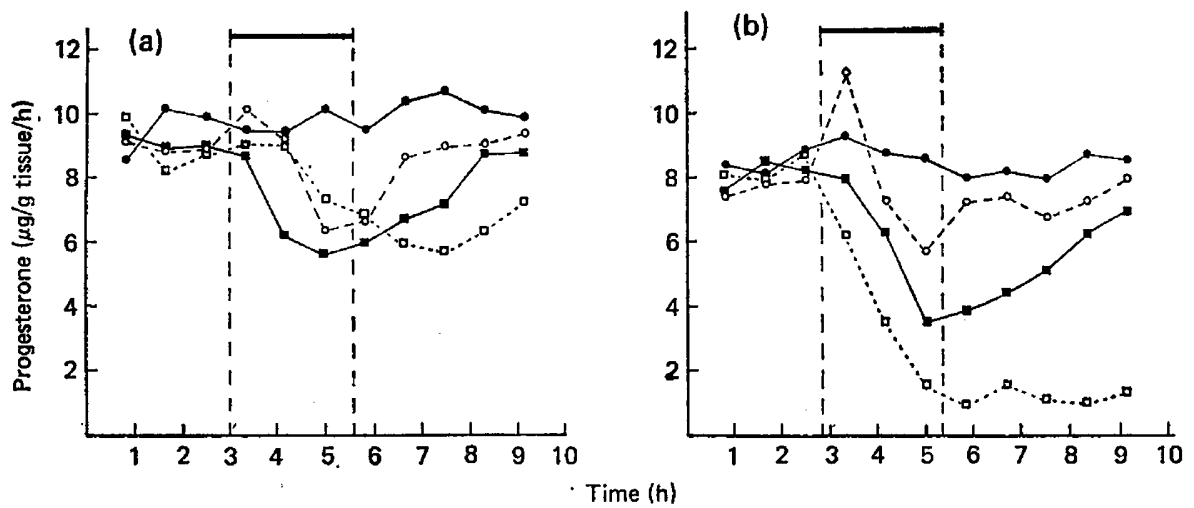

Text-fig. 2. Progesterone secretion by pig corpus luteum tissue (mid-II stage) superfused with medium 199 alone (e) or $1.0 \mu \mathrm{g}$ PGF- $2 \alpha / \mathrm{ml}(0)$ compared with that from luteal tissue superfused with endometrial superfusate ( $\square$ ) or uterine flushings ( $\square$ ) from sows during (a) the mid-luteal and (b) the late luteal phase of the oestrous cycle. Each point represents the mean of 4 experiments in which triplicate samples of superfusate were analysed in duplicate. S.E.M. values did not exceed $\pm 0.6 \mu \mathrm{g} \mathrm{g}^{-1} \mathrm{~h}^{-1}$ at any point. The bar and vertical broken lines indicate the period of superfusion. 
obtained from sows in the mid-luteal phase of the cycle again showed some inhibitory effect on progesterone secretion, but the superfusate from the endometrial tissue of sows in the late luteal phase of the cycle reduced progesterone secretion by over $90 \%$ relative to control conditions and no recovery of progesterone secretion occurred (Text-fig. 2).

The mean level of PGF- $2 \alpha$ in the uterine flushings of sows in the late luteal stage of the oestrous cycle was $1 \cdot 1 \mathrm{ng} / \mathrm{ml}$ medium, and when these flushings were superfused through luteal tissue (mid-II stage) secreting an average $0.3 \mathrm{ng}$ PGF- $2 \alpha / \mathrm{ml}$ medium (150 mg tissue) there was a net additive output of PGF- $2 \alpha$ secretion. The mean level of PGF- $2 \alpha$ in the endometrial superfusate of late luteal phase sows was $0.8 \mathrm{ng} / \mathrm{ml}$ medium, and when superfused through luteal tissue (mid-II stage) secreting an average $0.3 \mathrm{ng}$ PGF- $2 \alpha / \mathrm{ml}$ medium gave a net average output of $1.5 \mathrm{ng} / \mathrm{ml}$ medium. This small increase in output must have arisen by increased secretion or synthesis from the luteal tissue, but it did not approach the dose of PGF-2 $\alpha$ tested $(1.0 \mu \mathrm{g} / \mathrm{ml})$ which was not as effective as the endometrial superfusate in inhibiting progesterone secretion.

\section{Discussion}

These results demonstrate that low doses of PGF-2 $\alpha$ can reduce progesterone secretion by superfused corpora lutea from pigs in the middle of the luteal phase of the cycle, but that they were not as effective as uterine flushings or superfusates of endometrial strips. The results also confirm the findings of Schomberg (1967) that uterine flushings have luteolytic properties in pig granulosa cell cultures and that flushings from sows in the late phase of the cycle were more effective than those from midcycle, but demonstrate that the flushings are not truly luteolytic because the corpus luteum gradually recovers its ability to secrete progesterone. However, progesterone secretion was still depressed by $85-90 \% 4 \mathrm{~h}$ after the end of superfusion with endometrial superfusates and luteolysis had presumably occurred. The luteolytic action of the endometrial superfusates appears unlikely to be due to PGF-2 $\alpha$ alone, because this superfusate contained only $0.8 \mathrm{ng}$ PGF- $2 \alpha$.

It has previously been shown that the corpus luteum of the pig has a considerable capacity to secrete PGF-2 $\alpha$ (Patek \& Watson, 1976), but in the present experiments there was only a slight stimulation of PGF-2 $\alpha$ secretion. The overall output was about $1.6 \mathrm{ng}$ PGF- $2 \alpha / \mathrm{ml}$ medium and it seems unlikely that this concentration could have caused the luteolysis obtained in view of the results with much higher doses of exogenous PGF-2 $\alpha$. The prolonged effect of the uterine superfusate compared with exogenous PGF-2 $\alpha$ suggests that some factor other than, or possibly in combination with, PGF- $2 \alpha$ is responsible for luteolysis by initiating some irreversible process within the luteal cells. This factor could be an activated or protected form of prostaglandin which is stable in vivo, thus permitting the systemic activity suggested from the studies of Anderson (1966) on unilateral pregnancy in pigs.

The fact that full activity of the luteolytic factor is not obtained in uterine flushings suggests either that it is strongly bound to the endometrium or that it is continuously synthesized and selected by the endometrium. Further studies are in progress to elucidate the nature and stability of this factor in endometrial superfusates.

We thank Mrs Joanne Raeburn and Miss Ruth MacCormack for extensive technical assistance; the M.R.C. for financial support; Professor E. W. Horton, University of Edinburgh, for antibodies to PGF-2 $\alpha$; and Dr J. E. Pike, Upjohn Company, U.S.A., for authentic prostaglandins.

\section{References}

ANDERSON, L.L. (1966) Pituitary-ovarian-uterine relationships in pigs. J. Reprod. Fert., Suppl. 1, 21-32.

DIEHL, J.R. \& DAY, B.M. (1973) Effect of prostaglandin $\mathrm{F}_{2 x}$ on luteal function in swine. J. Anim. Sci. 37, 308309 .
DieHL, J.R. \& DAY, B.M. (1974) Effect of prostaglandin $\mathbf{F}_{2 \alpha}$ on luteal function in swine. J. Anim. Sci. 39, $392-396$.

Dighie, K.K., Emslie, H.A., Henderson, L.K, RUTHERFoRd, F. \& Simon, L. (1975) The development 
of antisera to prostaglandins $B_{2}$ and $F_{2 \alpha}$ and their analysis using solid phase and double antibody methods. Br. J. Pharmac. 55, 505-514.

Gleeson, A.R., Thorburn, G.D. \& Cox, R.I. (1974) Prostaglandin $\mathrm{F}$ concentrations in the utero-ovarian venous plasma of the sow during the late luteal phase of the oestrous cycle. Prostaglandins 5, 521529.

Guthrie, H.D. \& Polge, C. (1976) Luteal function and oestrus in gilts treated with a synthetic analogue of prostaglandin $F_{2 \alpha}(I C I 79,939)$ at various times during the oestrous cycle. J. Reprod. Fert. 48, 423-425.

HANSEN, H.S. (1976)15-Hydroxyprostaglandin dehydrogenase. A review. Prostaglandins 12, 647-679.

Mozluono, M.P.E., Bazer, F.W. \& Thatcher, W.W. (1976) A study of prostaglandin $F_{2 x}$ as the luteolysis in swine. I. Effect of prostaglandin $F_{2 \alpha}$ in hysterectomised gilts. Prostaglandins 11, 737-743.

NisWENDER, G.D. \& MidGLEY, A.R., Jr (1970) Hapten radioimmunoassay for steroid hormones. In Im- munologic Methods in Steroid Determination, pp. 149-174. Eds F. G. Peron \& B. V. Caldwell. AppletonCentury-Crofts, New York.

Patek, C.E. \& Watson, J. (1976) Prostaglandin F and progesterone secretion by porcine endometrium and corpus luteum in vitro. Prostaglandins 12, 97-111.

SchomberG, D.W. (1967) A demonstration in vitro of luteolytic activity in pig uterine flushings. $J$. Endocr. 38, 359-360.

Seaton, B., Lusty, J. \& Watson, J. (1976) A practical model for steroid hormone radioimmunoassays. J. Steroid Biochem. 7, 511-516.

Spies, H.G., Zimmerman, D.R., Self, H.L. \& Casida, L.E. (1960) Maintenance of early pregnancy in ovariectomized gilts treated with gonadal hormones. J. Anim. Sci. 19, 114-118.

Watson, J. \& Leask, J.T.S. (1975) Superfusion in vitro in the study of ovarian steroidogenesis. J. Endocr. 64, 163-173.

Received 18 February 1977 